\title{
REVIEW
}

\section{Osteoporosis in men: a cellular endocrine perspective of an increasingly common clinical problem}

\author{
R J Byers, J A Hoyland and I P Braidman \\ Musculoskeletal Research Group, University of Manchester Medical School, Stopford Building, Oxford Road, Manchester M13 9PT, UK \\ (Requests for offprints should be addressed to I P Braidman; Email: Isobel.Braidman@man.ac.uk)
}

\begin{abstract}
Although it has been accepted that osteoporosis is common in women, only recently have we become aware that it is also widespread in men; one in twelve men in the UK have osteoporosis. In many cases, there are recognisable causes for their osteoporosis, but a significant proportion (approximately one third) of these men have idiopathic disease. A major problem is that these cases are difficult to treat. An important therapeutic strategy would be to identify men at risk from osteoporosis sufficiently early, so that they can begin preventative measures. Moreover, development of novel means of treating these men would be an important clinical advance. With the emphasis on osteoporosis in women, however, the cellular and molecular basis for male idiopathic osteoporosis (MIO) is still poorly understood. Nevertheless, there are some aspects of skeletal regulation which may be specific for men and which could form the basis for addressing these problems. Thus, the importance of oestrogen in maintaining the adult skeleton in men as well as women implies that bone
\end{abstract}

cells in men can respond to low levels of the hormone. Both oestrogen receptor (ER) $\alpha$ and $\beta$ are expressed in bone in vivo, which may be important for oestrogen action on bone in men. Furthermore, in osteoporosis generally, there is increasing evidence for defective osteoblast differentiation such that there is a surfeit of adipocytes over osteoblasts. A low peak bone mass is a powerful risk factor for osteoporosis in later life; bone formation and, by implication, osteoblast differentiation, is key to the mechanism by which it is accrued. GH and IGFs are important for regulating osteoblast differentiation. Evidence now suggests that they are associated with bone mineral density, particularly in men. The genes for ERs, GH and IGF-I might be useful candidates with which we can begin to detect men at risk from osteoporosis. Furthermore, the mechanisms by which oestrogen, GH and IGF-I regulate the male skeleton could provide the basis for developing novel means of treating MIO.

Journal of Endocrinology (2001) 168, 353-362

\section{Features of male osteoporosis}

Osteoporosis affects approximately one third of women in the United Kingdom, and this has overshadowed the disease in men. It is now recognised that one in twelve men in Western countries have osteoporosis; 30\% of all hip fractures are in men (Eastell et al. 1998) and it accounts for at least one quarter of the total $\mathcal{L}_{1} 1$ billion burden of osteoporosis on the National Health Service in the United Kingdom. Moreover, recent observations of Ismail et al. (2000) indicate that the effects of the disease in men are at least as severe as in women. There are well-recognised risk factors for men; for example, treatment with antiinflammatory steroids, tobacco and alcohol consumption, and hypogonadism. At least a third of men with osteoporosis, however, have idiopathic disease. Why certain men have male idiopathic osteoporosis (MIO) and whether suitable treatment can be developed for them are major questions. Due to the emphasis on osteoporosis in women, however, the cellular and molecular basis for MIO is still poorly understood. In this article, we wish to review some of the fundamental mechanisms of skeletal regulation in order to ascertain if there are aspects of them which are specific to men, and which might form the basis for detecting men at risk from the disease and to review suitable treatments for MIO patients.

The standard World Health Organisation definition of osteoporosis in women is of a bone mineral density which is 2.5 standard deviations below that of a healthy normal control. Evidence suggests that the same definition can be applied to men, if based on gender-specific $\mathrm{T}$ scores (Selby et al. 2000). A typical clinical presentation is often that of long bone fracture following a non-traumatic event, or crush fractures of the vertebrae. In both men and women, 
bone mass adaptation to mechanical loading or deformation is thought crucial to preservation of skeletal structure and there is evidence that this may be hormone sensitive (Notelovitz et al. 1991). Intrinsic to maintenance of bone mineral density and structural integrity of the skeleton is the mechanism of bone remodelling. A major purpose of this process is replacement of old bone and it depends upon a balance between bone resorption, by osteoclasts, and bone formation through osteoblast activity. Osteoporotic bone loss is due to an imbalance in bone remodelling; either increased bone resorption, decreased bone formation or a combination of the two. Following the menopause, this bone loss is emphasised further through the increased initiation rate of bone remodelling cycles. Although raised osteoclasis has been regarded as a classic feature of postmenopausal bone loss in women (Cohen-Solal et al. 1995, Eriksen et al. 1999), histomorphometric classification of bone biopsies from over 140 women with postmenopausal osteoporosis demonstrates a minimum of five different combinations of osteoblast and osteoclast dysfunction (Rehman et al. 1995), involving changes in cell number with or without altered cell activity. Similar investigations of osteoporosis in men have been less extensive, but indications are that, although bone turnover may be increased, reduced trabecular number or size is a common feature of men with osteoporosis (Francis et al. 1989, Mosekilde 1989).

\section{Importance of oestrogens for maintaining bone in men and women}

It is well recognised that oestrogens are important for maintaining bone mineral density and skeletal structure in women; falling oestrogen levels in women during the menopause causes bone loss leading to osteoporosis. Likewise, androgens were thought to exert a similar effect on the male skeleton (Orwoll 1996). Indeed, hypogonadism and lowered testosterone levels are an important cause of osteoporosis in men. Our understanding of gonadal steroid action on bone has now altered radically, largely due to reports describing men either with a null mutation of oestrogen receptor (ER) (Smith et al. 1994) or aromatase genes (Morishima et al. 1995, 1997, Bilezikian et al. 1998). In both situations, although testosterone was synthesised and the androgen receptor (AR) unaffected, there was abnormal skeletal development and marked osteopenia. Furthermore, although there are reports that testosterone treatment improved bone mineral density in hypogonadal men (Behre et al. 1997), osteoporotic patients with Klinefelter's disease did not respond to this treatment (Wong et al. 1993), nor was it effective in treating males with aromatase deficiency (Carani et al. 1997). They, however, responded to oestrogen. A key question is the identity of androgen target cells in the adult male skeleton. Although AR expression has been reported in bone cells in vitro (Colvard et al. 1989) and in the growth plate of adsolescents (Abu et al. 1997), it is low in vivo in mature bone cells of adult men and women (Braidman et al. $2000 a$ ), in agreement with previous reports that AR expression is age and site dependent (Kasperk et al. 1997). Androstenedione treatment, however, reduces loss of cancellous bone in ovariectomised rats, even when aromatase activity was inhibited (Lea et al. 1998), but it is not known if this is relevant to the skeleton in adult men. Whether testosterone per se has a direct action on the adult male skeleton is still unclear, and it may be that it influences bone indirectly, either through muscle or changes in calcium regulation. The possibility remains that a major function of testosterone in the maintenance of adult bone, even in men, is to be the source of oestrogen. Indeed, it has now been proposed that bone loss in ageing men and women is associated with falling oestrogen levels (Khosla et al. 1998, Riggs et al. 1998). Further, in men, bone mineral density (Slemenda et al. 1997) and indices of bone formation (Anderson et al. 1998) are correlated positively with oestrogen levels. This was observed even when eugonadal men with osteoporosis were treated with testosterone. Moreover, in these patients there was no correlation between bone formation and testosterone levels (Anderson et al. 1997). A weaker association was reported between oestrogen and bone resorption (Slemenda et al. 1997). Although it has been suggested that, in postmenopausal women, high doses of oestrogen stimulate osteoblast function (Tobias \& Compston 1999), overall, the evidence reviewed above for the importance of oestrogen to bone formation in men, implies that osteoblasts may also be sensitive to lower circulating levels of male oestrogen.

\section{ER expression in the skeleton}

It has been known for some time that osteoblasts express ER and respond to oestrogen in vitro, with respect to synthesis of bone matrix proteins (Eriksen et al. 1988, Komm et al. 1988, Benz et al. 1991), growth factors and markers of osteoblast differentiation (Ernst \& Rodan 1991, Bodine et al. 1997, Kassem et al. 1998, Oursler 1998, Tau et al. 1998). Human cells across the osteoblast lineage express 'classic' ER $\alpha$ protein and mRNA in vivo and in vitro (Braidman et al. 1995, Hoyland et al. 1997, 1999, Kusec et al. 1998, Oreffo et al. 1999a). In vitro transfection studies (Ernst et al. 1991, Harris et al. 1995) demonstrate that the receptor may be responsible for many effects of oestrogen on osteoblast-like cells. The open epiphyses and marked bone loss in the adult man with a null mutation in $\mathrm{ER} \alpha$ (Smith et al. 1994) are further indications of its importance to the male skeleton. Nevertheless, although there is some reduction in bone mineral density of ER $\alpha$ knockout mice, ovariectomy of these animals produced a more profound bone loss (Pan et al. 1997). One possibility is that other receptors may be important for oestrogen 
action on the mouse skeleton. A second ER (ER $\beta$ ) is now recognised (Kuiper et al. 1996) and there is evidence for its expression in rat bone (Onoe et al. 1997, Windahl et al. 2000). Skeletal abnormalities in ER $\beta$ knockout mice, however, are surprisingly subtle, in that the bone mineral content of the cortices is increased only in adult females; males and immature animals remain unaffected (Windahl et al. 1999). ER $\beta$, however, is expressed in transformed fetal human cells of osteoblast lineage in vitro (Arts et al. 1997) and in the growth plate of adolescent boys and girls (Vidal et al. 1999). The role of ER $\beta$ in oestrogen action on the adult human skeleton is unclear and is a matter for current debate. Investigations conducted in our laboratory (Braidman et al. 2001) demonstrate that it is clearly expressed in osteoblasts and some osteocytes equally well in both adult men and women, although it is uncertain, at present, whether the same cells express both ER $\alpha$ and $\operatorname{ER} \beta$.

Whether or not oestrogens act directly on osteoclasts is less clear; there is evidence which suggests that the hormone may influence bone-resorbing cells indirectly in the mouse, via cells of osteoblast lineage (Jilka et al. 1992). Studies with avian osteoclasts, however, demonstrate that oestrogens can act on these cells directly (Oursler et al. 1991, 1993, Robinson et al. 1996) and there are some indications for a similar action with osteoclasts of human origin (Mano et al. 1996, Kameda et al. 1997). Expression of ER $\alpha$ in mammalian osteoclasts, however, is controversial; some groups report receptor expression, either of mRNA or protein, in mature cells (Mano et al. 1996, Hoyland et al. 1997, Pederson et al. 1997) but others demonstrate its expression only in immature osteoclasts (Huang et al. 1998, Kusec et al. 1998, Oreffo et al. 1999b). In contrast, our own observations (Braidman et al. 2001) demonstrate clear ER $\beta$ expression in human osteoclasts in vivo, in both adult men and women, and show that the receptor is relatively abundant in these cells. This might provide a mechanism by which oestrogens may act on osteoclasts directly.

Overall, although receptor expression early in the osteoblast lineage is still unclear, the evidence suggests that $\operatorname{ER} \alpha$ and $\operatorname{ER} \beta$ are both expressed in the later stages of differentiation. This could be of considerable importance to men, as their bone must respond to relatively low constant oestrogen levels, compared with large variations in circulating concentrations of the hormone experienced by pre-menopausal women. The presence of the two receptor isoforms provides a means of amplifying the effects of the small oestrogen concentrations in men. If the same cells express both receptors, this could be achieved through heterodimerisation (Cowley et al. 1997, Ogawa et al. 1998). Alternatively, if $\mathrm{ER} \alpha$ and $\mathrm{ER} \beta$ are similarly expressed in different cells of the osteoblast lineage, even low oestrogen concentrations could influence a wide spectrum of gene expression and thereby a variety of biological effects. A similar situation has been discussed for neural tissue (Kuiper et al. 1998). Such mechanisms as these may be the basis for the strong correlation between oestrogen levels in men with both bone mineral density and bone formation (Slemenda et al. 1997, Anderson et al. 1998, Khosla et al. 1998, Riggs et al. 1998).

\section{Oestrogen and MIO}

The notion that falling oestrogen levels in ageing men are responsible for bone loss, analogous to the situation in postmenopausal women (Slemenda et al. 1997, Khosla et al. 1998) has been developed further to provide an explanation for MIO (Riggs et al. 1998). Whether this is true for all MIO cases is, however, open to debate. In a small group of younger MIO patients, oestrogen levels (both total and free) were significantly lower than in the matched control group (Gillberg et al. 1999), although it is important to note that levels of the hormone in all the subjects were within the normal range. A similar study of older men with idiopathic osteoporosis (Resch et al. 1992) demonstrated that although oestrogen levels in patients were lower than in controls, there was no significant difference between them. Examination of the data from both these studies indicates that there may be a group of MIO patients with significantly lower oestrogen levels than their normal counterparts. That these hormone levels are within the normal range, however, attests to the sensitivity with which the skeleton in men may respond to oestrogen, as discussed previously in this article. Thus, a small decrease in circulating oestrogen levels may be sufficient to cause a fall in bone mineral density and, thereby, risk of osteoporosis. Other patients, in both these studies, had oestrogen levels identical to age-matched controls. Observations from our own laboratory (Anderson et al. 1998) demonstrate this in a larger group of men with idiopathic osteoporosis who were relatively young $(<55$ years of age). We hypothesised that in some of these MIO patients with normal oestrogen levels, responses of bone cells to oestrogen might be impaired, possibly through defective ER expression. We therefore investigated the expression of ER $\alpha$ protein in sections of bone biopsies from a group of younger men ( $<56$ years of age) with MIO. There was a marked loss of receptor protein expression in their osteoblasts and osteocytes, although receptor mRNA was still expressed (Braidman et al. $2000 a, b)$. Whether or not all MIO patients with normal oestrogen levels have defective expression of ER $\alpha$ is not known. Loss of ER $\beta$ expression in bone cells may also be associated with MIO, and this requires further investigation.

In all three studies (Resch et al. 1992, Anderson et al. 1998, Gillberg et al. 1999), there were men with normal bone mineral density but relatively low oestrogen levels; likewise, in many older men, oestrogen levels fall but they do not proceed to develop osteoporosis. Clearly, there are 
other factors important in the aetiology of $\mathrm{MIO}$; for example, there are reports of decreased circulating insulinlike growth factors (IGF) in some men with idiopathic disease (Kurland et al. 1997, 1998). This is of particular interest, as IGF-I levels correlate positively with bone mineral density in men but not in women (Janssen et al. 1998) and introduces the possibility that some aspects of the underlying mechanisms for osteoporosis are gender specific. Whether these features protect bone in men from the effect of, for example, falling oestrogen levels, is a question of considerable importance and may depend upon their role in bone formation and osteoblast differentiation.

\section{Osteoblast differentiation and osteoporosis}

Osteoblast differentiation from the stromal stem cell pool is essential to development and maintenance of the normal skeleton. The high proportion of osteoporotic cases in which there is reduced osteoblast number and activity, irrespective of whether osteoclasis is raised (Rehman et al. 1995), indicates that, in many cases, defective osteoblastogenesis is important to the aetiology of the disease. Marrow stromal pluripotent stem cells are the common progenitors of the osteoblast, chondroblast, fibroblast and adipocyte differentiation pathways, (Bab et al. 1985, 1986, Owen \& Friedenstein 1988), which are controlled by complex interactions between growth factors and cytokines (Locklin et al. 1995, Kuznetsov et al. 1997). The transforming growth factor- $\beta$ (TGF $\beta$ ) superfamily, which includes the bone morphogenic proteins (BMPs), is important in this regard; BMP-2 and BMP-7 stimulate osteoblast differentiation in vitro from stromal stem cell progenitors by acting on osteoblast-specific transcription factors (Yeh et al. 1998, Gori et al. 1999). Furthermore, growth hormone $(\mathrm{GH})$ stimulates osteoblast differentiation in vivo (Kroger et al. 1997) and in cultured stromal osteoblast progenitors, in the absence or presence of IGF-I and -II (Langdahl et al. 1998a), although there is some suggestion that the IGFs and the IGF-binding proteins (IGFBP) may be more important in later stages of osteoblast differentiation (Thomas et al. 1999a). The exact involvement of oestrogen in osteoblast differentiation is still uncertain; there are indications that GH may be important for early commitment to the osteoblast lineage, whereas oestrogen may act only on the later stages (Loveridge et al. 1996).

There is a close inverse association between differentiation from the stromal stem pool of osteoblasts with that of adipocytes (Bennett et al. 1991, Beresford et al. 1992). The current view is that there may be a plasticity between the two lineages or that they are derived from common precursors. Certainly factors like the BMPs, which stimulate osteoblastogenesis, concomitantly repress adipocyte differentiation from stromal stem cell populations in vitro (Gori et al. 1999). The observation that in osteoporosis there is an increase of bone marrow adipocytes, at the expense of osteoblasts (Burkhardt et al. 1987), therefore suggests a defect on osteoblast differentiation from the stromal stem cells, which favours adipogenesis. To investigate this further, we compared the ratio of adipose tissue to haematopoietic/stromal tissue in trabecular bone of osteoporotic patients with that in normal controls, and found that it was increased significantly in the patients. Evaluation of the histomorphometric indices of osteoblast activity indicates that the increased volume of adipose tissue is associated with reduced bone formation. Moreover, if adipocytic/haematopoietic ratio is used as a proxy in assessing the amount of stromal tissue present, then there is a strong association between variability in this parameter and trabecular bone apposition. Overall, this supports the hypothesis that osteoporosis results from a clonal switch in differentiation of early stromal cells to the adipocytic pathway. Such a switch would also result in a decrease in the number of osteoblasts in osteoporotic bone, a finding we have previously demonstrated (Rehman et al. 1995).

Such impairment in osteoblast differentiation could prevent bone formation from matching raised bone turnover, resulting, for example, from lowered oestrogen levels in either men or women, or through defective responses of bone cells to oestrogen, as may be the case in some MIO patients. This further suggests that whatever the cause of the increased bone turnover, either lowered oestrogen levels or other factors, only those individuals with sufficiently impaired osteoblast differentiation would present with osteoporosis. From this perspective, it could be argued that lowered oestrogen levels may not always result in the disease, and implies that understanding the defects in osteoblast differentiation may lead to a means of predicting those at risk from osteoporosis.

Reports of increased osteogenesis in animal models, in which there is over-expression of cfos and the related Fra-1 transactivation factors, demonstrate the importance of these local factors in the regulation of osteoblast differentiation (Jochum et al. 2000). Over-expression of a naturally occurring truncated transcription factor, delta FosB, however, stimulated osteoblastogenesis but reduced adipogenesis (Sabatakos et al. 2000). Adipogenesis may further influence osteoblastogenesis through the action of the body mass regulator, leptin. In addition to its central role in controlling metabolism, body weight and gonadal function, it has been shown to inhibit bone formation, in experimental animals, through the central nervous system (Ducy et al. 2000). Studies on human marrow stromal cells in vitro, however, indicate that it can act directly on them to enhance osteoblast differentiation, and decrease adipogenesis (Thomas et al. 1999b). Whether expression of cfos, FosB or leptin is altered in osteoporosis in general, or specifically in male osteoporosis, is yet to be determined. Another possibility is that decreased synthesis or function of BMPs may also be important in osteoporosis but for 
men, specifically, lowered IGF-I levels or activity may be of especial relevance (Janssen et al. 1998, Kurland et al. 1997, 1998), since this might lead to reduced osteoblast differentiation. This further suggests that there are aspects of adipocyte and osteoblast differentiation which may be specific to understanding osteoporosis in men.

\section{Peak bone mass as a determinant of osteoporosis}

Many of the basic mechanisms by which bone mass is accrued, and the factors which determine bone loss in osteoporosis, are similar in both men and women. Bone mass in an adult, at a specific time-point, is the net result of subsequent bone loss from his or her peak bone mass. There is complex interplay between environmental and genetic factors, which affect either bone formation or bone loss. This has been studied extensively in this context, but mostly in women. Of the few studies with men, investigations of elderly male twins demonstrated that environmental and lifestyle factors were more important than inheritance in determining bone loss (Christian et al. 1989, Slemenda et al. 1992). Even in elderly women it has been suggested that the contribution of genetic factors to bone turnover and bone loss is likely to be small (Garnero et al. 1996). In any event, a high rate of bone loss may not necessarily lead to osteoporosis, if it is offset against a relatively high peak bone mass. Indeed, it is peak bone mass which is recognised as an important determinant for osteoporosis in later life (Johnston \& Slemenda 1993, 1994, Teegarden et al. 1995).

Peak bone mass is accrued between 20 and 35 years of age. Although some environmental and lifestyle factors, particularly physical fitness and exercise, may be important influences on bone mass in young adult males (Casez et al. 1995), in contrast with bone loss in later life, a major component of peak bone mass in men is determined by genetic factors (Ettinger et al. 1997). Thus, the high bone mass in black Americans, compared with their counterparts, is reflected more by ethnic differences in peak bone mass than in bone turnover (Ettinger et al. 1997, Bikle et al. 1999). Genetic determinants of peak bone may, therefore, be predictors for later osteoporosis (Johnston \& Slemenda 1994, Kelly \& Harris 1995, Deng et al. 1999a).

Specific genes and their polymorphisms have been investigated for association with bone mass, e.g. Sp1 binding site of the collagen gene (Grant et al. 1996, Langdahl et al. 1998b, Uitterlinden et al. 1998), the receptor for 1,25 dihydroxy vitamin $\mathrm{D}_{3}$, (Morrison et al. 1994, Riggs et al. 1995, Eccleshall et al. 1998), interleukin 6 (Murray et al. 1997), interleukin 1 receptor (Keen et al. 1998), TGF $\beta$ (Bertoldo et al. 2000) and parathyroid hormone receptor type 1 (Duncan et al. 1999). The studies were all carried out in either women or populations of older subjects of an age when accretion of bone mass has ceased and bone loss has begun. It is therefore uncertain whether these gene polymorphisms are associated with peak bone mass, or if they are relevant specifically to men. Polymorphisms of the gene for ER $\alpha$, however, may be of interest in view of the potential sensitivity of the male skeleton to oestrogen, and the importance of ER $\alpha$ expression to some men with idiopathic osteoporosis, discussed earlier in this article. Moreover, ER $\alpha$ polymorphisms have been associated with bone mineral density in normal men (Ongphiphadhanakul et al. 1998a), although this study was with men of all ages. Furthermore, there is evidence that ER $\alpha$ polymorphisms are associated with bone mineral density in women, although this is dependent on the site of measurement, age and ethnicity of the population (Deng et al. 1999b, Mizunuma et al. 1997, Ongphiphadhanakul et al. 1998b, Vandevyver et al. 1999). It is still unclear whether this is also true for polymorphisms of this gene and peak bone mass in men.

\section{Osteoblast differentiation and potential predictors of peak bone mass in men}

Bone formation is undoubtedly central to the mechanism by which peak bone mass is attained in both men and women. On this basis, factors important in regulating osteoblast differentiation would also be key to attaining peak bone mass. In osteoporosis, there is impaired osteoblast differentiation, which, as discussed earlier, favours adipogenesis at the expense of osteoblastogenesis. If, in some patients, such a defect were to be present throughout life, then it may also be associated with lower peak bone mass. Polymorphisms of genes for factors which are important to the plasticity between adipogenesis and osteoblastogenesis may therefore be suitable candidates for predicting osteoporosis. The question now arises as to whether any of them might be specific for osteoporosis in men. The influence of GH and IGF-I on osteoblast differentiation has already been discussed, so it is especially noteworthy that in men aged between 20 and 40 years bone mass is associated with GH secretion. Moreover, the higher bone mineral density in Afro-Americans is associated with levels of this hormone in men but not in women (Wright et al. 1995, 1996). Furthermore, GH-dependent IGFBP is an important determinant of bone mass in healthy men (Johansson et al. 1994) and the positive correlation between IGF-I and bone mineral density, which is specific to men (Janssen et al. 1998), has been discussed earlier in this article. As oestrogens influence $\mathrm{GH}$ and IGF levels, the importance of interactions between these hormones cannot be discounted in this context (Holmes \& Shalet 1996). Factors which regulate lean body mass may also be important; it is correlated with bone mineral density in men aged 19-29 years, i.e. at accretion of peak bone mass (Nuti et al. 1995). In women, however, reports of its relationship to bone mineral density have depended on the bone mass parameter used, and fat 
body mass may also exert an equally important influence (Khosla et al. 1996). Regulation of lean body mass may, therefore, be important to peak bone mass in men specifically.

\section{Development of suitable treatments for men with idiopathic osteoporosis}

Bisphosphonates and hormone replacement therapy are now the most often used treatments for osteoporosis in general. Although oestrogen-based therapy is obviously inappropriate for male osteoporosis, the recent development of selective ER modulators (SERMs) maybe provide the basis for acceptable treatments. For example, raloxifene may act on ERs in bone and cardiac tissues specifically, thereby obviating the 'female' reproductive effects of oestrogen (Gustafsson 1998). Moreover, although raloxifene binds to ER $\alpha$ in bone (Bryant et al. 1999) and thereby transactivates oestrogen-responsive genes, together with other SERMs, it has a more potent effect via ER $\beta$ (Paech et al. 1997). Bone, which expresses both ER isoforms, could be particularly sensitive to relatively low doses of raloxifene, which might help avoid any potential side-effects in the treatment of male osteoporosis. Furthermore, there is the possibility that oestrogen may have an anabolic effect on bone under certain conditions (Tobias \& Compston 1999) and this may also apply to SERMs. The bisphosphonates were developed as agents which suppressed osteoclastic bone resorption and there is evidence that the latest generations of these drugs acts through the mevalonate pathway of osteoclasts (Russell \& Rogers 1999, Rogers et al. 2000). Although in some obvious respects they are the most appropriate available treatment for male osteoporosis, the possible importance of defective osteoblastogenesis in some men with idiopathic disease implies that bisphosphonates may be less than satisfactory in some cases. Nevertheless, there are recent reports of significantly increased bone mineral density in a doubleblind, placebo-controlled study of alendronate treatment of men with osteoporosis (Orwoll et al. 2000). Other approaches have concentrated on development of anabolic therapies for osteoporosis; for example, the analogues of parathyroid hormone (Stewart et al. 2000) which may prove to be more suitable. On the basis of the discussion in this article, investigating the mechanism by which $\mathrm{GH}$ and IGF-I regulate osteoblast differentiation may provide the basis for treatment which may be especially beneficial for the treatment of MIO. A clearer understanding of the cellular and molecular biology of osteoblastogenesis will undoubtedly reveal novel approaches to treating male osteoporosis.

In conclusion, although many aspects of osteoporosis are common to both men and women, there may, indeed, be some significant features of skeletal regulation of especial relevance to the disease in men. Thus, bone is particularly sensitive to the low levels of circulating oestrogen in men and evidence suggests that GH and IGF-I are important for accretion of male peak bone mass. Further investigation of osteoblast differentiation and of oestrogen, $\mathrm{GH}$ and IGF-I action on bone and bone cells in men will yield some specific determinants of male osteoporosis and could initiate novel therapies for this disease.

\section{Acknowledgements}

We wish to thank Professor A J Freemont and Dr P L Selby for their helpful comments and discussion during the preparation of this manuscript.

\section{References}

Abu EO, Horner A, Kusec V, Triffitt JT \& Compston JE 1997 The localization of androgen receptors in human bone. Journal of Clinical Endocrinology and Metabolism 82 3493-3497.

Anderson FH, Francis RM, Peaston RT \& Wastell HJ 1997 Androgen supplementation in eugonadal men with osteoporosis: effects of six months' treatment on markers of bone formation and resorption. Journal of Bone and Mineral Research 12 472-478.

Anderson FH, Francis RM, Selby PL \& Cooper C 1998 Sex hormones and osteoporosis in men. Calcified Tissue International 62 185-188.

Arts J, Kuiper GGJM, Janssen JMMF, Gustafsson JA, Lowik CWGM, Pols HAP \& VanLeeuwen JPTM 1997 Differential expression of estrogen receptors alpha and beta MRNA during differentiation of human osteoblast SV-HFO cells. Endocrinology 138 5067-5070.

Bab I, Ashton BA, Gazit D, Marx G, Williamson M \& Owen ME 1985 Kinetics of bone-formation from marrow stromal cells. Bone 6 480.

Bab I, Ashton BA, Gazit D, Marx G, Williamson MC \& Owen ME 1986 Kinetics and differentiation of marrow stromal cells in diffusion chambers in vivo. Journal of Cell Science 84 139-151.

Behre HM, Kliesch S, Leifke E, Link TM \& Nieschlag E 1997 Long-term effect of testosterone therapy on bone mineral density in hypogonadal men. Journal of Clinical Endocrinology and Metabolism 82 2386-2390.

Bennett JH, Joyner CJ, Triffitt JT \& Owen ME 1991 Adipocytic cells cultured from marrow have osteogenic potential. Journal of Cell Science 99 131-139.

Benz DJ, Haussler MR \& Komm BS 1991 Estrogen binding and estrogenic responses in normal human osteoblast-like cells. Journal of Bone and Mineral Research 6 531-541.

Beresford JN, Bennett JH, Devlin C, Leboy PS \& Owen ME 1992 Evidence for an inverse relationship between the differentiation of adipocytic and osteogenic cells in rat marrow stromal cell-cultures. Journal of Cell Science 102 341-351.

Bertoldo F, D’Agruma L, Furlan F, Colapietro F, Lorenzi MT, Maioran N, Iolascon A, Zelante L, Locascio V \& Gasparini P 2000 Transforming growth factor-beta 1 gene polymorphism, bone turnover, and bone mass in Italian postmenopausal women. Journal of Bone and Mineral Research 15 634-639.

Bikle DD, Ettinger B, Sidney S, Tekawa IS \& Tolan K 1999 Differences in calcium metabolism between black and white men and women. Mineral and Electrolyte Metabolism 25 178-184.

Bilezikian JP, Morishima A, Bell J \& Grumbach MM 1998 Increased bone mass as a result of estrogen therapy in a man with aromatase deficiency. New England Journal of Medicine 339 599-603.

Bodine PVN, Green J, Harris HA, Bhat RA, Stein GS, Lian JB \& Komm BS 1997 Functional properties of a conditionally phenotypic, 
estrogen-responsive, human osteoblast cell line. Journal of Cellular Biochemistry 65 368-387.

Braidman IP, Davenport LK, Carter DH, Selby PL, Mawer EB \& Freemont AJ 1995 Preliminary in situ identification of estrogen target-cells in bone. Journal of Bone and Mineral Research 10 74-80.

Braidman IP, Baris C, Selby PL, Adams JE, Freemont AJ \& Hoyland JA $2000 a$ Preliminary report of impaired oestrogen receptor-alpha expression in bone, but no involvement of androgen receptor, in male idiopathic osteoporosis. Journal of Pathology 192 90-96.

Braidman I, Baris C, Wood L, Selby P, Adams J, Freemont A \& Hoyland JA $2000 b$ Preliminary evidence for impaired estrogen receptor alpha protein expression in osteoblasts and osteocytes from men with idiopathic osteoporosis. Bone 26 423-427.

Braidman IP, Hainey L, Batra G, Selby PL, Saunders PTK \& Hoyland JA 2001 Localisation of estrogen receptor beta protein expression in adult human bone. Journal of Bone and Mineral Research (In Press).

Bryant HU, Glasebrook AL, Yang NN \& Sato M 1999 An estrogen receptor basis for raloxifene action in bone. Journal of Steroid Biochemistry and Molecular Biology 69 37-44.

Burkhardt R, Kettner G, Bohm W, Schmidmeier M, Schlag R, Frisch B, Mallmann B, Eisenmenger W \& Gilg T 1987 Changes in trabecular bone, hematopoiesis and bone-marrow vessels in aplastic-anemia, primary osteoporosis, and old-age - a comparative histomorphometric study. Bone 8 157-164.

Carani C, Qin K, Simoni M, Fustini M, Serpente S, Boyd J, Korach KS \& Simpson ER 1997 Effect of testosterone and estradiol in a man with aromatase deficiency. New England Journal of Medicine 337 91-95.

Casez JP, Fischer S, Stussi E, Stalder H, Gerber A, Delmas PD, Colombo JP \& Jaeger P 1995 Bone mass at lumbar spine and tibia in young males - impact of physical fitness, exercise and anthropology parameters - a prospective study in a cohort of military recruits. Bone 17 211-219.

Christian JC, Yu PL, Slemenda CW \& Johnston CC 1989 Heritability of bone mass - a longitudinal-study in aging male twins. American Journal of Human Genetics 44 429-433.

Cohen-Solal ME, Graulet AM, Gueris J, Denne MA, Bergot C, Morieux C, Sedel L, Kuntz D \& Devernejoul MC 1995 Bone resorption at the femoral-neck is dependent on local factors in nonosteoporotic late postmenopausal women - an in vitro and in vivo study. Journal of Bone and Mineral Research 10 307-314.

Colvard DS, Eriksen EF, Keeting PE, Wilson EM, Lubahn DB, French FS, Riggs BL \& Spelsberg TC 1989 Identification of androgen receptors in normal human osteoblast-like cells. PNAS $\mathbf{8 6}$ 854-857.

Cowley SM, Hoare S, Mosselman S \& Parker MG 1997 Estrogen receptors alpha and beta form heterodimers on DNA. Journal of Biological Chemistry 272 19858-19862.

Deng HW, Stegman MR, Davies KM, Conway T \& Recker RR $1999 a$ Genetic determination of variation and covariation of peak bone mass at the hip and spine. Journal of Clinical Densitometry 2 251-263.

Deng HW, Li J, Li JL, Johnson M, Gong G \& Recker RR 19996 Association of VDR and estrogen receptor genotypes with bone mass in postmenopausal Caucasian women: different conclusions with different analyses and the implications. Osteoporosis International 9 499-507.

Ducy P, Amling M, Takeda S, Priemel M, Schilling AF, Beil FT, Shen JH, Vinson C, Rueger JM \& Karsenty G 2000 Leptin inhibits bone formation through a hypothalamic relay: a central control of bone mass. Cell 100 197-207.

Duncan EL, Brown MA, Sinsheimer J, Bell J, Carr AJ, Wordsworth BP \& Wass JAH 1999 Suggestive linkage of the parathyroid receptor type 1 to osteoporosis. Journal of Bone and Mineral Research 14 1993-1999.

Eastell R, Boyle IT, Compston J, Cooper C, Fogelman I, Francis RM, Hosking DJ, Purdie DW, Ralston S, Reeve J, Reid DM, Russell
RGG \& Stevenson JC 1998 Management of male osteoporosis: Report of the UK Consensus Group. Quarterly Journal of Medicine 91 71-92.

Eccleshall TR, Garnero P, Gross C, Delmas PD \& Feldman D 1998 Lack of correlation between start codon polymorphism of the vitamin $\mathrm{D}$ receptor gene and bone mineral density in premenopausal French women: The OFELY Study. Journal of Bone and Mineral Research 13 31-35.

Eriksen EF, Colvard DS, Berg NJ, Graham ML, Mann KG, Spelsberg TC \& Riggs BL 1988 Evidence of estrogen-receptors in normal human osteoblast-like cells. Science 241 84-86.

Eriksen EF, Langdahl B, Vesterby A, Rungby J \& Kassem M 1999 Hormone replacement therapy prevents osteoclastic hyperactivity: a histomorphometric study in early postmenopausal women. Journal of Bone and Mineral Research 14 1217-1221.

Ernst M \& Rodan GA 1991 Estradiol regulation of insulin-like growth factor-I expression in osteoblastic cells - evidence for transcriptional control. Molecular Endocrinology 5 1081-1089.

Ernst M, Parker MG \& Rodan GA 1991 Functional estrogenreceptors in osteoblastic cells demonstrated by transfection with a reporter gene containing an estrogen response element. Molecular Endocrinology 5 1597-1606.

Ettinger B, Sidney S, Cummings SR, Libanati C, Bikle DD, Tekawa IS, Tolan K \& Steiger P 1997 Racial differences in bone density between young adult black and white subjects persist after adjustment for anthropometric, lifestyle, and biochemical differences. Journal of Clinical Endocrinology and Metabolism 82 429-434.

Francis RM, Peacock M, Marshall DH, Horsman A \& Aaron JE 1989 Spinal osteoporosis in men. Bone and Mineral 5 347-357.

Garnero P, Arden NK, Griffiths G, Delmas PD \& Spector TD 1996 Genetic influence on bone turnover in postmenopausal twins. Journal of Clinical Endocrinology and Metabolism 81 140-146.

Gillberg P, Johansson AG \& Ljunghall S 1999 Decreased estradiol levels and free androgen index and elevated sex hormone-binding globulin levels in male idiopathic osteoporosis. Calcified Tissue International 64 209-213.

Gori F, Thomas T, Hicok KC, Spelsberg TC \& Riggs BL 1999 Differentiation of human marrow stromal precursor cells: bone morphogenetic protein-2 increases OSF2/CBFA1, enhances osteoblast commitment, and inhibits late adipocyte maturation. Journal of Bone and Mineral Research 14 1522-1535.

Grant SFA, Reid DM, Blake G, Herd R, Fogelman I \& Ralston SH 1996 Reduced bone density and osteoporosis associated with a polymorphic Sp1 binding site in the collagen type I alpha 1 gene. Nature Genetics 14 203-205.

Gustafsson JA 1998 Raloxifene: magic bullet for heart and bone? Nature Medicine 4 152-153.

Harris SA, Tau KR, Enger RJ, Toft DO, Riggs BL \& Spelsberg TC 1995 Estrogen response in the Hfob-119 human fetal osteoblastic cell-line stably transfected with the human estrogen-receptor gene. Journal of Cellular Biochemistry 59 193-201.

Holmes SJ \& Shalet SM 1996 Role of growth hormone and sex steroids in achieving and maintaining normal bone mass. Hormone Research 45 86-93.

Hoyland JA, Mee AP, Baird P, Braidman IP, Mawer EB \& Freemont AJ 1997 Demonstration of estrogen receptor mRNA in bone using in situ reverse-transcriptase polymerase chain reaction. Bone $\mathbf{2 0}$ 87-92.

Hoyland JA, Baris C, Wood L, Baird P, Selby PL, Freemont AJ \& Braidman IP 1999 Effect of ovarian steroid deficiency on oestrogen receptor alpha expression in bone. Journal of Pathology 188 294-303.

Huang WH, Lau ATT, Daniels LL, Fujii H, Seydel U, Wood DJ, Papadimitriou JM \& Zheng MH 1998 Detection of estrogen receptor alpha, carbonic anhydrase II and tartrate-resistant acid phosphatase mRNAs in putative mononuclear osteoclast precursor cells of neonatal rats by fluorescence in situ hybridization. Journal of Molecular Endocrinology 20 211-219. 
Ismail AA, O'Neill TW, Cooper C \& Silman AJ 2000 Risk factors for vertebral deformities in men: relationship to number of vertebral deformities. Journal of Bone and Mineral Research 15 278-283.

Janssen JAMJ, Burger H, Stolk RP, Grobbee DE, de Jong FH, Lamberts SWJ \& Pols HAP 1998 Gender-specific relationship between serum free and total IGF-I and bone mineral density in elderly men and women. European Journal of Endocrinology 138 627-632.

Jilka RL, Hangoc G, Girasole G, Passeri G, Williams DC, Abrams JS, Boyce B, Broxmeyer H \& Manolagas SC 1992 Increased osteoclast development after estrogen loss - mediation by interleukin-6. Science 257 88-91.

Jochum W, David JP, Elliott C, Wutz A, Plenk H, Matsuo K \& Wagner EF 2000 Increased bone formation and osteosclerosis in mice overexpressing the transcription factor Fra-1. Nature Medicine 6 980-984.

Johansson AG, Forslund A, Hambraeus L, Blum WF \& Ljunghall S 1994 Growth hormone-dependent insulin-like growth-factor binding-protein is a major determinant of bone-mineral density in healthy men. Journal of Bone and Mineral Research 9 915-921.

Johnston CC \& Slemenda CW 1993 Determinants of peak bone mass. Osteoporosis International 3 S54-S55.

Johnston CC \& Slemenda CW 1994 Peak bone mass, bone loss and risk of fracture. Osteoporosis International 4 43-45.

Kameda T, Mano H, Yuasa T, Mori Y, Miyazawa K, Shiokawa M, Nakamaru Y, Hiroi E, Hiura K, Kameda A, Yang NN, Hakeda Y \& Kumegawa M 1997 Estrogen inhibits bone resorption by directly inducing apoptosis of the bone-resorbing osteoclasts. Journal of Experimental Medicine 186 489-495.

Kasperk C, Helmboldt A, Borcsok I, Heuthe S, Cloos O, Niethard F \& Ziegler R 1997 Skeletal site-dependent expression of the androgen receptor in human osteoblastic cell populations. Calcified Tissue International 61 464-473.

Kassem M, Okazaki R, Harris SA, Spelsberg TC, Conover CA \& Riggs BL 1998 Estrogen effects on insulin-like growth factor gene expression in a human osteoblastic cell line with high levels of estrogen receptor. Calcified Tissue International 62 60-66.

Keen RW, Woodford-Richens KL, Lanchbury JS \& Spector TD 1998 Allelic variation at the interleukin-1 receptor antagonist gene is associated with early postmenopausal bone loss at the spine. Bone $\mathbf{2 3}$ 367-371.

Kelly PJ \& Harris M 1995 Genetic-regulation of peak bone mass. Acta Paediatrica 84 24-30.

Khosla S, Atkinson EJ, Riggs BL \& Melton LJ 1996 Relationship between body composition and bone mass in women. Journal of Bone and Mineral Research 11 857-863.

Khosla S, Melton LJ, Atkinson EJ, O'Fallon WM, Klee GG \& Riggs BL 1998 Relationship of serum sex steroid levels and bone turnover markers with bone mineral density in men and women: a key role for bioavailable estrogen. Journal of Clinical Endocrinology and Metabolism 83 2266-2274.

Komm BS, Terpening CM, Benz DJ, Graeme KA, Gallegos A, Korc M, Greene GL, O’Malley BW \& Haussler MR 1988 Estrogen binding, receptor messenger-RNA, and biologic response in osteoblast-like osteo-sarcoma cells. Science 241 81-84.

Kroger H, Soppi E \& Loveridge N 1997 Growth hormone, osteoblasts, and marrow adipocytes: a case report. Calcified Tissue International 61 33-35.

Kuiper GGJM, Enmark E, Pelto Huikko M, Nilsson S \& Gustafsson JA 1996 Cloning of a novel estrogen receptor expressed in rat prostate and ovary. PNAS 93 5925-5930.

Kuiper GGJM, Shughrue PJ, Merchenthaler I \& Gustafsson JA 1998 The estrogen receptor beta subtype: a novel mediator of estrogen action in neuroendocrine systems. Frontiers in Neuroendocrinology 19 253-286.
Kurland ES, Rosen CJ, Cosman F, McMahon D, Chan F, Shane E, Lindsay R, Dempster D \& Bilezikian JP 1997 Insulin-like growth factor-I in men with idiopathic osteoporosis. Journal of Clinical Endocrinology and Metabolism 82 2799-2805.

Kurland ES, Chan FKW, Rosen CJ \& Bilezikian JP 1998 Comments - Normal growth hormone secretory reserve in men with idiopathic osteoporosis and reduced circulating levels of insulin-like growth factor-I. Journal of Clinical Endocrinology and Metabolism $\mathbf{8 3}$ 2576-2579.

Kusec V, Virdi AS, Prince R \& Triffitt JT 1998 Localization of estrogen receptor-alpha in human and rabbit skeletal tissues. Journal of Clinical Endocrinology and Metabolism 83 2421-2428.

Kuznetsov SA, Friedenstein AJ \& Robey PG 1997 Factors required for bone marrow stromal fibroblast colony formation in vitro. British Journal of Haematology 97 561-570.

Langdahl BL, Kassem M, Moller MK \& Eriksen EF 1998a The effects of IGF-I and IGF-II on proliferation and differentiation of human osteoblasts and interactions with growth hormone. European Journal of Clinical Investigation 28 176-183.

Langdahl BL, Ralston SH, Grant SFA \& Eriksen EF 1998b An Sp1 binding site polymorphism in the COLIA1 gene predicts osteoporotic fractures in both men and women. Journal of Bone and Mineral Research 13 1384-1389.

Lea CK, Moxham V, Reed MJ \& Flanagan AM 1998 Androstenedione treatment reduces loss of cancellous bone volume in ovariectomised rats in a dose-responsive manner and the effect is not mediated by oestrogen. Journal of Endocrinology 156 331-339.

Locklin RM, Williamson MC, Beresford JN, Triffitt JT \& Owen ME 1995 in vitro effects of growth-factors and dexamethasone on rat marrow stromal cells. Clinical Orthopaedics and Related Research 313 $27-35$.

Loveridge N, Grau E, Noble BS, Witt JM \& Gevers EF 1996 Does $\mathrm{GH}$ act as a differentiation switch between adipocytes and osteoblasts? Journal of Bone and Mineral Research 11 Abstract O8.

Mano H, Yuasa T, Kameda T, Miyazawa K, Nakamaru Y, Shiokawa M, Mori Y, Yamada T, Miyata K, Shindo H, Azuma H, Hakeda Y \& Kumegawa M 1996 Mammalian mature osteoclasts as estrogen target cells. Biochemical and Biophysical Research Communications 223 637-642.

Mizunuma H, Hosoi T, Okano H, Soda M, Tokizawa T, Kagami I, Miyamoto S, Ibuki Y, Inoue S, Shiraki M \& Ouchi Y 1997 Estrogen receptor gene polymorphism and bone mineral density at the lumbar spine of pre- and postmenopausal women. Bone $\mathbf{2 1}$ 379-383.

Morishima A, Grumbach MM, Simpson ER, Fisher C \& Qin K 1995 Aromatase deficiency in male and female siblings caused by a novel mutation and the physiological role of estrogens. Journal of Clinical Endocrinology and Metabolism 80 3689-3698.

Morishima A, Grumbach MM \& Bilezikian JP 1997 Estrogen markedly increases bone mass in an estrogen deficient young man with aromatase deficiency. Journal of Bone and Mineral Research 12 (Suppl 1) Abstract 96.

Morrison NA, Qi JC, Tokita A, Kelly PJ, Crofts L, Nguyen TV, Sambrook PN \& Eisman JA 1994 Prediction of bone-density from vitamin-D receptor alleles. Nature 367 284-287.

Mosekilde L 1989 Sex-differences in age-related loss of vertebral trabecular bone mass and structure-biomechanical consequences. Bone 10 425-432.

Murray RE, McGuigan F, Grant SFA, Reid DM \& Ralston SH 1997 Polymorphisms of the interleukin- 6 gene are associated with bone mineral density. Bone 21 89-92.

Notelovitz M, Martin D, Tesar R, Khan FY, Probart C, Fields C \& McKenzie L 1991 Estrogen therapy and variable-resistance weight training increase bone-mineral in surgically menopausal women. Journal of Bone and Mineral Research 6 583-590.

Nuti R, Martini G \& Gennari C 1995 Age-related changes of whole skeleton and body-composition in healthy men. Calcified Tissue International 57 336-339. 
Ogawa S, Inoue S, Watanabe T, Hiroi H, Orimo A, Hosoi T, Ouchi Y \& Muramatsu M 1998 The complete primary structure of human estrogen receptor beta (HER beta) and its heterodimerization with $\mathrm{ER}$ alpha in vivo and in vitro. Biochemical and Biophysical Research Communications 243 122-126.

Ongphiphadhanakul B, Rajatanavin R, Chanprasertyothin S, Piaseu N \& Chailurkit L 1998a Serum oestradiol and oestrogen-receptor gene polymorphism are associated with bone mineral density independently of serum testosterone in normal males. Clinical Endocrinology 49 803-809.

Ongphiphadhanakul B, Rajatanavin R, Chanprasertyothin S, Piaseu N, Chailurkit L, Sirisriro R \& Komindr S 1998 bstrogen receptor gene polymorphism is associated with bone mineral density in premenopausal women but not in postmenopausal women. Journal of Endocrinological Investigation 21 487-493.

Onoe Y, Miyaura C, Ohta H, Nozawa S \& Suda T 1997 Expression of estrogen receptor beta in rat bone. Endocrinology 138 4509-4512.

Oreffo ROC, Kusec V, Romberg S \& Triffitt JT 1999a Human bone marrow osteoprogenitors express estrogen receptor-alpha and bone morphogenetic proteins 2 and 4 mRNA during osteoblastic differentiation. Journal of Cellular Biochemistry 75 382-392.

Oreffo ROC, Kusec V, Virdi AS, Flanagan AM, Grano M, Zambonin Zallone A \& Triffitt JT 1999 bxpression of estrogen receptor-alpha in cells of the osteoclastic lineage. Histochemistry and Cell Biology 111 125-133.

Orwoll ES 1996 Androgens as anabolic agents for bone. Trends in Endocrinology and Metabolism 7 77-84.

Orwoll E, Ettinger M, Weiss S, Miller P, Kendler D, Graham J, Adami S, Weber K, Lorenc R, Pietschmann P, Vandormael K, Lombardi A, Adachi JD, Bell N, Body JJ, Castro A, Daifotis A, Felsenberg D, Gilchrist N, Hoffman A, Maricic M, Rizzoli R, Silverman S \& Valeriano J 2000 Alendronate for the treatment of osteoporosis in men. New England Journal of Medicine 343 604-610.

Oursler MJ 1998 Estrogen regulation of gene expression in osteoblasts and osteoclasts. Critical Reviews in Eukaryotic Gene Expression 8 125-140.

Oursler MJ, Osdoby P, Pyfferoen J, Riggs BL \& Spelsberg TC 1991 Avian osteoclasts as estrogen target-cells. PNAS 88 6613-6617.

Oursler MJ, Pederson L, Pyfferoen J, Osdoby P, Fitzpatrick L \& Spelsberg TC 1993 Estrogen modulation of avian osteoclast lysosomal gene-expression. Endocrinology 132 1373-1380.

Owen M \& Friedenstein AJ 1988 Stromal stem-cells-marrow-derived osteogenic precursors. Ciba Foundation Symposia 136 42-60.

Paech K, Webb P, Kuiper GGJM, Nilsson S, Gustafsson JA, Kushner PJ \& Scanlan TS 1997 Differential ligand activation of estrogen receptors ER alpha and ER beta at AP1 sites. Science 277 1508-1510.

Pan LC, Ke HZ, Simmons HA, Crawford DT, ChidseyFrink KL, McCurdy SP, Schafer JR, Kimbro KS, Taki M, Korach KS \& Thompson DD 1997 Estrogen receptor-alpha knockout ERKO mice lose trabecular and cortical bone following ovariectomy. Journal of Bone and Mineral Research 12 (Suppl 1) Abstract 126.

Pederson L, Kremer M, Foged NT, Winding B, Ritchie C, Fitzpatrick LA \& Oursler MJ 1997 Evidence of a correlation of estrogen receptor level and avian osteoclast estrogen responsiveness. Journal of Bone and Mineral Research 12 742-752.

Rehman MTA, Hoyland JA, Denton J \& Freemont AJ 1995 Histomorphometric classification of postmenopausal osteoporosis implications for the management of osteoporosis. Journal of Clinical Pathology 48 229-235.

Resch H, Pietschmann P, Woloszczuk W, Krexner E, Bernecker P \& Willvonseder R 1992 Bone mass and biochemical parameters of bone metabolism in men with spinal osteoporosis. European Journal of Clinical Investigation 22 542-545.

Riggs BL, Nguyen TV, Melton LJ, Morrison NA, Ofallon WM, Kelly PJ, Egan KS, Sambrook PN, Muhs JM \& Eisman JA 1995 The contribution of vitamin-D-receptor gene alleles to the determination of bone-mineral density in normal and osteoporotic women. Journal of Bone and Mineral Research 10 991-996.

Riggs BL, Khosla S \& Melton LJ 1998 A unitary model for involutional osteoporosis: estrogen deficiency causes both type I and type II osteoporosis in postmenopausal women and contributes to bone loss in aging men. Journal of Bone and Mineral Research $\mathbf{1 3}$ 763-773.

Robinson JA, Riggs BL, Spelsberg TC \& Oursler MJ 1996 Osteoclasts and transforming growth factor-beta: estrogen-mediated isoform-specific regulation of production. Endocrinology 137 615-621.

Rogers MJ, Gordon S, Benford HL, Coxon FP, Luckman SP, Monkkonen J \& Frith JC 2000 Cellular and molecular mechanisms of action of bisphosphonates. Cancer 88 2961-2978.

Russell RG \& Rogers MJ 1999 Bisphosphonates: from the laboratory to the clinic and back again. Bone 25 97-106.

Sabatakos G, Sims NA, Chen J, Aoki K, Kelz MB, Amling M, Bouali Y, Mukhopadhyay K, Ford K, Nestler EJ \& Baron R 2000 Overexpression of delta FosB transcription factors increases bone formation and inhibits adipogenesis. Nature Medicine 6 985-990.

Selby PL, Davies M \& Adams JE 2000 Do men and women fracture bones at similar bone densities? Osteoporosis International $\mathbf{1 1}$ 153-157.

Slemenda CW, Christian JC, Reed T, Reister TK, Williams CJ \& Johnston CC 1992 Long-term bone loss in men - effects of genetic and environmental factors. Annals of Internal Medicine 117 286-291.

Slemenda CW, Longcope C, Zhou LF, Hui SL, Peacock M \& Johnston CC 1997 Sex steroids and bone mass in older men positive associations with serum estrogens and negative associations with androgens. Journal of Clinical Investigation 100 1755-1759.

Smith EP, Boyd J, Frank GR, Takahashi H, Cohen RM, Specker B, Williams TC, Lubahn DB \& Korach KS 1994 Estrogen resistance caused by a mutation in the estrogen-receptor gene in a man. New England Journal of Medicine 331 1056-1061.

Stewart AF, Cain RL, Burr DB, Jacob D, Turner CH \& Hock JM 2000 Six-month daily administration of parathyroid hormone and parathyroid hormone-related protein peptides to adult ovariectomized rats markedly enhances bone mass and biomechanical properties: a comparison of human parathyroid hormone 1-34, parathyroid hormone-related protein 1-36, and SDZ-parathyroid hormone 893. Journal of Bone and Mineral Research 15 1517-1525.

Tau KR, Hefferan TE, Waters KM, Robinson JA, Subramaniam M, Riggs BL \& Spelsberg TC 1998 Estrogen regulation of a transforming growth factor-beta inducible early gene that inhibits deoxyribonucleic acid synthesis in human osteoblasts. Endocrinology 139 1346-1353.

Teegarden D, Proulx WR, Martin BR, Zhao J, McCabe GP, Lyle RM, Peacock M, Slemenda C, Johnston CC \& Weaver CM 1995 Peak bone mass in young women. Journal of Bone and Mineral Research 10 711-715.

Thomas T, Gori F, Spelsberg TC, Khosla S, Riggs BL \& Conover CA 1999a Response of bipotential human marrow stromal cells to insulin-like growth factors: effect on binding protein production, proliferation, and commitment to osteoblasts and adipocytes. Endocrinology 140 5036-5044.

Thomas T, Gori F, Khosla S, Jensen MD, Burguera B \& Riggs BL $1999 b$ Leptin acts on human marrow stromal cells to enhance differentiation to osteoblasts and to inhibit differentiation to adipocytes. Endocrinology 140 1630-1638.

Tobias JH \& Compston JE 1999 Does estrogen stimulate osteoblast function in postmenopausal women? Bone 24 121-124.

Uitterlinden AG, Burger H, Huang WJ, Yue F, McGuigan FEA, Grant SFA, Hofman A, van Leeuwen JPTM, Pols HAP \& Ralston SH 1998 Relation of alleles of the collagen type I alpha 1 gene 
to bone density and the risk of osteoporotic fractures in postmenopausal women. New England Journal of Medicine 338 1016-1021.

Vandevyver C, Vanhoof J, Declerck K, Stinissen P, Vandervorst C, Michiels L, Cassiman JJ, Boonen S, Raus J \& Geusens P 1999 Lack of association between estrogen receptor genotypes and bone mineral density, fracture history, or muscle strength in elderly women. Journal of Bone and Mineral Research 14 1576-1582.

Vidal O, Kindblom LG \& Ohlsson C 1999 Expression and localization of estrogen receptor-beta in murine and human bone. Journal of Bone and Mineral Research 14 923-929.

Windahl SH, Vidal O, Andersson G, Gustafsson JA \& Ohlsson C 1999 Increased cortical bone mineral content but unchanged trabecular bone mineral density in female $E R \beta-/-$ mice. Journal of Clinical Investigation 104 895-901.

Windahl SH, Norgard M, Kuiper GGJM, Gustafsson JA \& Andersson G 2000 Cellular distribution of estrogen receptor beta in neonatal rat bone. Bone 26 117-121.

Wong FHW, Pun KK \& Wang C 1993 Loss of bone mass in patients with Klinefelters-syndrome despite sufficient testosterone replacement. Osteoporosis International 3 3-7.
Wright NM, Renault J, Willi S, Veldhuis JD, Pandey JP, Gordon L, Key LL \& Bell NH 1995 Greater secretion of growth-hormone in black than in white men - possible factor in greater bone-mineral density - a clinical research-center study. Journal of Clinical Endocrinology and Metabolism 80 2291-2297.

Wright NM, Papadea N, Willi S, Veldhuis JD, Pandey JP, Key LL \& Bell NH 1996 Demonstration of a lack of racial difference in secretion of growth hormone despite a racial difference in bone mineral density premenopausal in women - a clinical research center study. Journal of Clinical Endocrinology and Metabolism 81 1023-1026.

Yeh LCC, Betchel KP \& Lee JC 1998 Inhibition of BMP receptor synthesis by antisense oligonucleotides attenuates OP-1 action in primary cultures of fetal rat calvaria cells. Journal of Bone and Mineral Research 13 1870-1879.

Received 4 September 2000

Revised manuscript received 13 November 2000

Accepted 16 November 2000 